\title{
Het begrip 'literatuur' binnen het literatuuronderwijs
}

Jeroen Dera

De meest gestelde vraag aan een literatuurwetenschapper is waarschijnlijk: 'Wat is nu eigenlijk literatuur?' Ook als docent moet je een zinnig antwoord op die vraag kunnen geven. Het lastige is daarbij dat er geen eenduidige definitie van literatuur bestaat. Definities van literatuur zijn namelijk altijd contextgebonden. In de zeventiende eeuw betekende 'literatuur' iets anders dan rond 1900, en tegenwoordige definities verschillen weer van die uit het begin van de twintigste eeuw. Ook de geografische context is van belang: in Nederland betekent 'literatuur' iets anders dan in bijvoorbeeld West-Afrika. De meest zuivere definitie van het begrip is daarom: 'Literatuur is datgene wat in een bepaalde tijd en in een bepaalde context literatuur genoemd wordt.'

De hierboven gebruikte definitie van het concept 'literatuur' wordt ook wel een functionalistische of institutionele definitie genoemd. Als je op die manier naar literatuur kijkt, is het belangrijk om in kaart te brengen wie precies mogen uitmaken wat literatuur genoemd wordt (en wat dus niet). Wie bepaalt met andere woorden de criteria? In de literatuursociologie is het gebruikelijk om het antwoord op die vraag te zoeken door zogenaamde instituties te analyseren. Onder instituties worden de instellingen, organisaties en (groepen van) personen aangeduid die zich bezighouden met het verspreiden, becommentariëren en waarderen van teksten die voor het etiket 'literatuur' in aanmerking komen (Vaessens \& Bijl 2013, 28). Bekende en veel bestudeerde instituties zijn de literaire kritiek, de bibliotheek, de boekhandel en de uitgeverij.

Ook het literatuuronderwijs geldt als een institutie die mede bepaalt wat als literatuur beschouwd wordt en wat niet. Het begrip 'literatuur' wordt in het voortgezet onderwijs niet vastomlijnd ingevuld. In het vmboprogramma wordt de term niet eens gebruikt: het gaat daar om 'fictie'. In het examenprogramma voor havo en vwo wordt echter van leerlingen gevraagd dat zij beargumenteerd verslag kunnen uitbrengen van 'leeservaringen met een aantal door hen geselecteerde literaire werken'. Er wordt daarbij niet toegelicht wanneer een werk literair is. In de praktijk leidt dit ertoe dat individuele (bovenbouw)docenten als poortwachter fungeren en bepalen welke teksten leerlingen wel en niet op hun leeslijst mogen zetten. In die zin beantwoorden literatuurdocenten aan wat Laan (2018) een 'medemaker' noemt: zij geven mede vorm aan wat binnen een gegeven context als literatuur wordt beschouwd.

Docenten verschillen sterk in hun opvattingen over literatuur (Janssen, 1998). Om die reden kan de vraag of een bepaald boek op 'de lijst' gezet mag worden tot verhitte discussies leiden. Want als het examenprogramma om 'literaire werken' vraagt, mag je dan bijvoorbeeld een 'literaire thriller' toestaan? Recente publicaties in de literatuurwetenschap kiezen wat dat betreft voor een sterk inclusief perspectief. Dorleijn, De Geest en Verstraeten (2017) wijzen er bijvoorbeeld op dat het begrip 'literatuur' verschillende praktijken dekt en dat de literaire cultuur in de 21 eeuw veel breder is dan ze pakweg honderd jaar geleden was. Tegenwoordig omvat 'literatuur' niet alleen de Klassiekers met hoofdletter K, maar ook populaire literatuur, jeugdliteratuur, non-fictieboeken en films, televisieseries en games die zich op de literaire traditie beroepen. Voor sommigen is dat standpunt omstreden. Voor hen gaat het bij literatuur om de schone letteren, en daar horen spannende detectives niet bij.

Tegenstanders van een inclusief literatuurconcept hanteren meestal de tegenhanger van een functionalistische of institutionele definitie, namelijk een essentialistische definitie van literatuur. Zij menen dat literaire teksten een aantal vaststelbare eigenschappen hebben waardoor ze onderscheiden kunnen worden van niet-literaire teksten, die dan meestal 'lectuur' worden genoemd. In veelgebruikte lesmethoden in het voortgezet onderwijs zien we dat essentialistische denken terug. Laagland, literatuur en lezer definieert literatuur bijvoorbeeld in termen van 'meerduidigheid' en 'open plekken', terwijl het zeer recente Nieuw Nederlands Literatuur de volgende conceptualisering bevat: 'Verzamelnaam voor teksten die een “diepere laag” hebben.' Die diepere laag zou tot uiting komen via kenmerken als complexiteit, originaliteit, onvoorspelbaarheid, bijzonder taalgebruik en ambiguïteit. De methode Dautzenberg: geschiedenis 
en theorie legt iets meer klemtoon op de subjectieve rol van de lezer in de toekenning van het etiket 'literair'. Hier wordt literatuur in eerste instantie gedefinieerd als 'teksten die gelezen worden omdat men ze mooi, aangrijpend, indrukwekkend vindt'. De vraag wie 'men' precies is, blijft onbeantwoord. Wel wordt later vastgesteld dat literatuur gewoonlijk als een vorm van 'kunst' wordt gezien, en dat het tegenwoordig minder helder is wat eronder valt dan in vroegere tijden.

Lesmethoden die een essentialistische definitie van literatuur hanteren, doen alsof er objectieve regels zijn waaraan je een literaire tekst kunt toetsen. In werkelijkheid zijn criteria als 'complexiteit' en 'dubbelzinnigheid' echter sterk normatief. Als docent kun je dus nooit neutraal over literatuur praten: je draagt altijd een zogenaamde poëtica (of: literatuuropvatting) uit. Eerder onderzoek naar literatuurdidactiek laat zien dat er verschillende docenttypologieën onderscheiden kunnen worden in het Nederlandse literatuuronderwijs. Aan de basis van dat onderzoek staat het proefschrift van Janssen (1998), waarin op basis van enquêtes onder 1200 bovenbouwdocenten Nederlands vier typen literatuurdocenten onderscheiden worden: de culturele vormer (met een focus op literatuurgeschiedenis en literaire stromingen), de literair-esthetische vormer (focus op literatuurtheorie en formele structuuranalyse), de maatschappelijke vormer (focus op de maatschappelijke achtergrond van teksten) en de individuele ontplooier (focus op de persoonlijke leesbeleving van leerlingen). Verboord (2003) heeft deze vier typen teruggebracht tot twee basisprofielen: cultuurgerichte en lezersgerichte docenten. Die beide groepen houden er een andere praktijk als poortwachter op na. Een thriller, bijvoorbeeld, past niet in de literatuuropvattingen van de cultuurgerichte docent, terwijl de lezersgerichte docent veel meer voor dat genre openstaat. In zijn onderzoek heeft Verboord (2006) laten zien dat de lezersgerichte benadering in de periode 1975-2000 steeds centraler is komen te staan in het Nederlandse literatuuronderwijs. Dat verklaart misschien ook de regelmatig terugkerende discussie rond de invulling van de 'leeslijst'. Het helpt ook begrijpen waarom steeds meer docenten Nederlands recente adolescentenromans geschikt vinden om in de bovenbouw te lezen (Sikkema, 2013).

Binnen een lezersgerichte benadering is de match tussen een leerling en een boek cruciaal. Baanbrekend in dit opzicht is het proefschrift van Witte (2008), waarin een model wordt gepresenteerd om leerling-lezers van verschillende competentieniveaus te koppelen aan boeken die qua niveau bij hen passen. Een aanzienlijk deel van de docenten gebruikt de website Lezen voor lijst, die gebaseerd is op Wittes onderzoek, als uitgangspunt voor tekstselectie in het literatuuronderwijs (Oberon, 2016). In die zin geeft de website mede vorm aan wat in het onderwijs 'literatuur' wordt genoemd. Wederom blijkt het begrip daarbij breed. Zo vallen onder Wittes 'Niveau 3' (het streefniveau van een havoleerling) zowel jeugdromans als boeken voor volwassenen. Ook staat een roman als Het gouden ei van Tim Krabbé (door sommige critici opgevat als een spannend boek zonder literaire waarde) naast een gecanoniseerd werk als Het bittere krmid van Margo Minco (de laatste P.C. Hooftprijswinnaar).

Websites als Lezen voor de lijst zijn voor leerlingen en docenten een handige keuzegids voor het literatuuronderwijs. Tegelijkertijd bepalen ze mede welke teksten onder leerlingen (blijven) circuleren. Ook in het Nederlandse onderwijs bestaan er regelrechte 'schoolklassiekers' die het beeld van literatuur voor menig leerling bepalen. Grootschalig onderzoek naar de teksten die examenkandidaten havo/vwo voor het schoolvak Nederlands lezen legt enkele patronen in dat beeld bloot (Dera, 2019). Het overgrote deel van de teksten die leerlingen selecteren is geschreven door mannen met een westerse achtergrond. Vrouwelijke auteurs en auteurs met een migratieachtergrond zijn op leeslijsten van leerlingen ondervertegenwoordigd. Dat patroon is ook zichtbaar in het leesgedrag van docenten Nederlands en in de leestips die startende leraren aan leerlingen geven (Dera, 2018; Dera \& Lommerde, 2020). 'Literatuur' is in het Nederlandse literatuuronderwijs met andere woorden ook op het vlak van gender en etniciteit geen neutraal begrip.

Er is nog relatief weinig onderzoek gedaan naar de werking van het begrip 'literatuur' in het voortgezet onderwijs. Het belangrijkste hiaat is de afwezigheid van het leerlingperspectief. Wat betekent het concept 'literatuur' eigenlijk volgens leerlingen? We weten ook weinig over de definities die docenten zelf hanteren (in en buiten hun lessen). Hoewel de studies van Verboord $(2003,2006)$ laten zien dat docenten sterker lezersgericht zijn geworden, is er niet systematisch onderzocht hoe rekbaar zij het literatuurbegrip vinden. 
Betekent een lezersgerichte basishouding in de praktijk bijvoorbeeld daadwerkelijk dat leerlingen een tekst als Gijp van Michel van Egmond voor Nederlands mogen lezen?

Een ander punt betreft de breedte van het literatuurbegrip. Vanuit vakdidactische hoek zijn onlangs pleidooien gehouden voor literatuuronderwijs waarin andere media zoals film en games een centrale plaats innemen (Groenendijk, 2018; Witte, Mantingh, \& Van Herten, 2017). In de hoek van de poëziedidactiek wordt dan weer een lans gebroken voor Instagramgedichten om de 'drempel' naar het poëziegenre te verlagen (Dera \& Van der Starre, 2019). Met de essentialistische definities uit de veelgebruikte lesmethoden staan die initiatieven op gespannen voet. Het zou dan ook interessant zijn om deze fenomenen te confronteren met de literatuuropvattingen die docenten en leerlingen er zelf op nahouden.

\section{Bibliografie}

Dera, J. (2018). De lezende leraar: Literatuuronderwijs in Nederland(s) als onderzoeksobject. Tijdschrift voor Nederlandse Taal- en Letterkunde (TNTL), 134(2), 146-170.

Dera, J. (2019). De praktijk van de leeslijst. Een onderzoek naar de inhoud en waardering van literatuurlijsten voor het schoolvak Nederlands op havo en vwo. Amsterdam: Stichting Lezen.

Dera, J. \& Lommerde, N. (2020). Persoonlijke voorkeuren, canonieke werken en leesadviezen: literatuur volgens leraren Nederlands in opleiding. Levende Talen Tijdschrift, 21(1), te verschijnen.

Dera, J. \& Van der Starre, K. (2019). Instagrampoëzie in de klas. Levende Talen Magazine, 107(6), 4-9.

Dorleijn, G., De Geest, D. \& Verstraeten, P. (2017). Elementaire deeltjes: literatuur. Amsterdam: AUP.

Groenendijk, R. (2018). Literatuuronderwijs in het licht van Bildung. Een pleidooi voor een bredere definitie van het begrip tekst in literatuuronderwijs. Levende Talen Magarine, 106(1), 12-15.

Janssen, T. (1998). Literatuuronderwijs bij benadering: een empirisch onderzoek naar de vormgeving en opbrengsten van bet literatuuronderwijs Nederlands in de bovenbouw van het havo en vwo. Amsterdam: Thesis Publishers.

Laan, N. (2018). Medemakers. Sociologie van literatuur en andere kunsten. Hilversum: Uitgeverij Verloren.

Oberon. (2016). Lees- en literatuuronderwijs in havo en vwo. Amsterdam: Stichting Lezen.

Sikkema, M. (2013). De opmars van adolescentenliteratuur: Onderzoek naar adolescentenliteratuur in het literatuuronderwijs Nederlands. Levende Talen Tijdschrift, 14(1), 37-47.

Vaessens, T. \& Bijl, P. (2013). Grondslagen. In J. Rock, G. Franssen \& F. Essink (eds.), Literatuur in de wereld: handboek moderne letterkunde. Nijmegen: Vantilt (pp. 13-94).

Verboord, M. (2003). Moet de meester dalen of de leerling klimmen? De invloed van literatuuronderwijs en ouders op het lezen van boeken tussen 1975 en 2000. Proefschrift Universiteit Utrecht.

Verboord, M. (2006). Veranderingen in benaderingen van literatuuronderwijs: literatuuropvattingen overgedragen door docenten Nederlands tussen 1975 en 2000. In G.J. Dorleijn \& K. van Rees (eds.), De productie van literatuur. Het literaire veld in Nederland 1800-2000. Nijmegen: Vantilt (pp. 217-238; 329-331).

Witte, T. (2008). Het oog van de meester. Een onderzoek naar de literaire ontwikkeling van havo-en vwo-leerlingen in de tweede fase van het voortgezet onderwijs. Delft: Eburon.

Witte, T., Mantingh, E. \& Van Herten, M. (2017). Doodtij in de delta. Stand en toekomst van het Nederlandse literatuuronderwijs. Spiegel der Letteren, 59(1), 115-143. 